\title{
Collaboration to Explore Teaching: A Case Study Report
}

The purpose of this study was to analyze the collaborative efforts of two EFL teachers to explore teaching with a view to solving problems in their respective classes. In so doing the study also attempted to investigate whether this process of collaborative reflection would lead to a change in these EFL teachers' instructional practices and attitudes toward teaching. The results of this qualitative research study indicate that during the process of collaboration, the participants formulated their own agenda for developing strategies to cope with their problems and for a possible change in their classroom practice. Moreover, the dialogue between the teachers seemed to affect their perception of an ideal teacher, although there was no change in their beliefs concerning to the extent to which they themselves had these characteristics of an ideal teacher.

\section{Introduction}

The study presented in this article is based on a pilot project focused on EFL teachers' collaborative reflection on individual teaching practice. The study draws on educational research and thought that focuses on the role of collaboration in teacher education (Davydov, 1995; Driver, Asako, Leech, Mortimer, \& Scott, 1994; Newman \& Holzman, 1995; Kauchak \& Eggen, 1997; Olson, 1997; Richardson, 1997; Roberts, 1998).

Some research indicates that activities that promote teacher learning engage them in "task focused talk" (Roberts, 1998, p. 45) with fellow teachers and others (i.e., supervisors, mentors) addressing their practices, beliefs, and the social pressures affecting their work. This dialogue is of special value in that it offers opportunities to clarify teachers' own meanings and helps them to build social relationships that support their changing views of themselves as teachers (Davydov, 1995; Driver et al., 1994; Kauchak \& Eggen, 1997; Olson, 1997). As Richardson (1997) argues, teacher change seems rooted in individual perceptions of self as influenced by experiences in the classroom and with teaching colleagues.

Collaboration in this sense can provide social support for reflection and opportunities to learn from peers or from less or more experienced colleagues. Collaboration can imply a variety of partnerships: collaboration in team teaching (Sturman, 1992; Bailey et al., 1995), collaboration in curriculum development (Nunan, 1992a), collaboration in teacher research (Bailey et al., 1995), and collaborative reflection on individual teaching practice (Farrel, 
1998). This study focuses on collaborative reflection on individual teaching practice.

\section{Teachers' Collaborative Reflection on Individual Practice}

A number of inservice education programs-in both ESL/EFL and other educational contexts-have focused on promoting teacher learning by engaging teachers in awareness-raising activities in which they examine their own routine practices and the values or assumptions underlying those practices. These programs have varied in their intensity from specifically interventionist programs that included teacher education activities and collaborative reflection with more experienced teachers (Roberts, 1998), to mentoring programs that stressed reflection, journal writing, discussion with colleagues, and classroom observation (Seaman, Meadon, \& Sweeny, 1997), to less structured programs where single teachers collaborated with researchers to explore their beliefs about teaching (Gebhard \& Motonaga, 1992; Farrel, 1998, in press). The common element in these studies is the presence of a less experienced teacher and a more experienced collaborator who work together to effect change. Indeed, as Freeman (1989) has commented, "one person cannot intervene to change another directly, therefore two individuals must collaborate to achieve that purpose" (p. 38).

Reports from these inservice education programs have demonstrated that engaging teachers in collaborative dialogue with peers, mentors, researchers, or supervisors, gave teachers an opportunity to engage in heightened reflection on their individual practices (Farrel, 1998; Gebhard \& Motonaga, 1992), a process that sometimes enabled them to change their teaching styles and behaviors (Farrel, in press; Roberts, 1988) and helped them to develop individual and collective resources for dealing with specific problems in their classrooms (Seaman et al., 1997). Roberts (1988), for example, in a study of a program specifically designed to promote teacher education and teacher change, suggests that changes to individual practice incorporated a change in teachers' attitudes toward students and an increase in their understanding of curriculum and field-specific terminology.

To date few, if any, studies in TESL/TEFL have simultaneously investigated the efficacy of teacher collaboration and familiarized teachers with professional development strategies, which is the purpose of this study. This is a particularly important area in TESL/TEFL contexts where teachers have relatively limited access to inservice professional development opportunities.

\section{The Study}

The purpose of this study was to analyze the collaborative efforts of two EFL teachers guided by a supervisor or researcher. It was intended to enable these teachers to explore teaching with a view to coping with problems in 
their respective classes. In so doing the study also attempted: (a) to help the teachers to develop strategies for professional development; and (b) to investigate whether the process of collaborative reflection would lead to a change in these EFL teachers' instructional practices and attitudes toward teaching.

Specifically, the study attempted to answer the following research question: Does collaborative reflection affect EFL teachers' classroom practice and EFL teachers' attitudes toward teaching? If so, how?

\section{The Setting}

The study presented in this article is based on a staff development project aimed at improving individual teacher practice at the English preparatory school of an English-medium Turkish university in Istanbul, Turkey. In December 1998 I was asked by the administrators of the university to help them set up a staff development program for the teachers working in the preparatory school. In discussions with the administrators, it was decided that I would start a pilot project with volunteer teachers and investigate the attitudes of these teachers toward the program. There were 18 teachers in this school, six native speakers of English ( 2 males, 4 females), and 12 Turkish EFL teachers ( 8 females, 4 males). The average teaching experience of these teachers was eight years.

I am a researcher who has taught English for 10 years and have eight years of experience as a teacher trainer. I called an initial meeting to explain the aims of the project to the teachers. Fifteen teachers attended this meeting, during which I informed them that the project would initially focus on identifying their particular instructional problems. The teachers would then engage in collaboration to explore their individual practice and develop strategies to cope with their classroom difficulties. Teachers were told that participation was voluntary and that any change would be initiated by them. Two teachers volunteered to participate in this pilot study.

\section{Participants}

One participant (Zeynep) was a 29-year-old female native Turkish-speaker who had five years of teaching experience. The other (Arzu) was a 32-yearold female native Turkish-speaker who had eight years of teaching experience.

Through discussions I discovered that these teachers had little experience in collaboration to explore their teaching. However, they pointed out that they would feel comfortable with each other during the process of their collaboration. I believed that sharing knowledge with a trusted colleague would help them recognize the benefits of pair work, and collaboration in this sense would gradually be developed. The teachers seemed to be willing to engage in this process of collaboration.

Broadly speaking, three major activities were envisaged for this project: (a) reflection and dialogue (collaboration in clarification and rethinking of 
perspectives); (b) reception (input of new information through suggested readings); and (c) performing the tasks related to data collection.

As a result of discussions with the teachers, I suggested they read the following books: Language Teaching Methodology (Nunan, 1992b) and Reflective Teaching in a Second Language Classroom (Richards \& Lockhart, 1995). These books introduce teachers to techniques that can be used to explore and improve their teaching practice. In consideration for their teaching load, I did not want to burden these teachers with a great deal of reading. However, I told them that if they wished, they could read other books or articles recommended in these two books.

\section{Data Collection}

Data came from six sources: (a) videotaped classroom instruction data; (b) stimulated recall data; (c) observers' field notes; (d) teachers' journals; (e) notes from the teachers' dialogue; and (f) self-reports of teachers' perceptions of an ideal teacher.

\section{Videotaped Classroom Instruction Data}

Thirteen full lessons from each teacher were observed by the other teacher and myself. These were videotaped during a 13-week block in the second semester of the academic year 1998-1999. To accustom the EFL learners and the teachers to the presence of the equipment and the observers, we videotaped a 10-minute segment of a regular lesson of each teacher before videotaping these 45 -minute lessons. The 10-minute segments were also used later for purposes that are discussed below.

\section{Stimulated Recall Data}

In collecting stimulated recall data, the procedures developed in both L1 and L2 educational research were used (Ericson \& Simon, 1980, Nunan, 1989). Teachers were shown their own videotaped lessons and asked to stop the tape at points where they recalled their thoughts or the reasons for their instructional decisions or actions. Before the stimulated recall procedure, for training purposes, I showed each of the teachers their 10-minute videotape until they felt they clearly understood what they were going to do. I transcribed videotaped classroom instruction and stimulated recall data following the transcription conventions given in Van Lier (1988, see Appendix). The teachers watched each other's video with me. Thus the stimulated recall technique was also applied in this case for professional development.

\section{Observers' Field Notes}

The observing teacher and I took field notes during each observation, the purpose of which was to clarify issues concerning teachers' practices and the strategies they used to deal with the problems they experienced in the classroom. Before the procedure, again for training purposes, each teacher and I 
observed a 10-minute lesson segment of the other teacher and took field notes. These notes were then compared to make the sure that the teachers understood what they were going to do.

\section{Teachers' Journals}

Both teachers kept journals about classroom events that impressed them and what they thought about them. They also wrote down their thoughts concerning the project and their role in it, their roles as teachers, and their reactions to the suggested readings. The teachers were encouraged to share their journals with each other and with me.

\section{Note From the Teachers' Dialogue}

The teachers met at least twice a week to discuss major issues concerning one specific problem in their respective classes and points they wished to focus on in relation to the lessons they observed; they then reported their impressions of the collaborative talk concerning their classroom practice in writing. The dialogue was not recorded; but every week the teachers shared their notes with me.

\section{Teachers' Perceptions of an Ideal Teacher}

The participants wrote a report at the beginning and end of the project comparing their own teaching with what they considered to be the characteristics of a good teacher. They then indicated whether they believed they possessed (indicated by $P$ in the tables) or were currently trying to improve (indicated by $W$ in the tables) each attribute they mentioned (see Tables 1 and 2). Thus the procedures followed for data collection also serve as training for the teachers in observation and research skills.

\section{Data Analysis}

In an attempt to answer the first part of the research question (whether collaborative reflection affected teachers' classroom practice), data from the teachers' journals, the observers' field notes, and stimulated recall protocols were examined. Following the practice in Carter (1993) and Freeman (1996), narratives (hereafter referred to as cases) were constructed from the data. These cases described a major problem each teacher had in her classroom and how she tried to cope with it. To cross-validate and supplement these cases, information was derived from the videotaped classroom instruction data. Next, each teacher was asked to read the cases reconstructed by the researcher and provide feedback so that I could solicit comments to confirm or refute my interpretations (Elbaz, 1990).

In an attempt to answer the second part of the research question (whether collaborative reflection affected teacher's attitudes toward teaching), the teachers' self-reports of beliefs about the characteristics of an ideal teacher and to what extent they had these characteristics were analyzed. In each 
self-report the participants' beliefs about qualities of an ideal teacher were classified into three categories: (a) personal qualities as a teacher; (b) teaching behavior; and (c) professional development, following which qualities in each category were listed. Each of the attributes was classified as to whether teachers felt they (a) possess or are (b) currently working on (W) (see Tables 1 and 2). The attributes reported at the beginning and end of the 12-week period were compared. The information gathered from the teachers' selfreports about their beliefs were cross-validated by comparing them with the teachers' journals, teachers' notes on their dialogue, and stimulated recall protocols.

\section{Results and Discussion}

To answer the first part of the research question, Does collaborative reflection affect EFL teachers' classroom practice? I focus on one specific classroom difficulty for each teacher.

\section{Zeynep's Case}

Zeynep was teaching grammar and listening skills to 19 pre-intermediatelevel graduate EFL students. Students are admitted to the first year of this university with a minimum of 550 on the TOEFL and 4.5 on the writing component of the TOEFL. Intermediate- or pre-intermediate-level students are those with scores below 550 on the TOEFL. Their placement in the intermediate or pre-intermediate level classes is based on their scores in the placement test administered by the School of Foreign Languages. Students in Zeynep's class began pressuring her for more grammar practice, and this issue was very much on Zeynep's mind. She believed that she was already teaching with a strong grammar orientation and that more mechanical practice would not help the students with language acquisition, claiming, "My recent readings in ELT gave me support for shying away from explicit grammar teaching. I know that this is no help for the process of language acquisition" (February 2, 1999, journal). So, as indicated in her journal, she decided to negotiate a solution to the problem by developing friendly relations and encouraging student involvement. In this way she thought she could create a more relaxed atmosphere for them to speak in English and forget about their perceived need to learn more grammar. She explained:

Maybe I thought I should be more friendly with them. Well I took a heater and tea bags and water to school. I offered some to my students. The breaks are too short to run off to get hot beverages, and one really needs them. So we carried the canteen into class. This operation may be the ticket to getting my students to loosen up and use whatever English they have, and forget about grammar. (February 17, 1998, journal) 
Zeynep observed that this action seemed to relax the students to a certain extent. She said, "They seemed to be more relaxed. And I really got interested in what they had to say. Once they start talking, there is much laughter and no sign of strain" (February 22, 1999, journal).

However, later on Zeynep seemed to lose her confidence about avoiding grammar practice and focusing instead on pair or group work for meaningful communication when some of her students did not do well on the common exam. Nevertheless, she still did not seem to think that she should provide more grammar practice to her students because she believed that this was not a need of most of the class:

Zeynep was talking about her problem with the class wanting grammar practice, explaining how the class spokesman who demanded the grammar practice told other students to stay during the break. She thought that maybe the others weren't insisting like this student was and that maybe her problems was really with just one student. (Arzu, March 17, 1999, notes on teacher dialogue)

Later, when Zeynep talked to her students about Arzu's suggestions, she found that they preferred additional written practice from a grammar book and that this was not the wish of only one student. So Zeynep decided to give the class grammar exercises for homework and check their answers in class.

Thus a brief analysis of Zeynep's case indicates that her basic problem was that she did not know how to cope with the incongruence between her beliefs and the learning preferences of her students. Zeynep believed that explicit grammar instruction did not help with language acquisition. She therefore did not wish to comply with her students' demands to give them more grammar exercises. However, Zeynep changed her attitude toward her students' learning styles through discussions with Arzu. She seems to have increased her flexibility about allowing students more control over their learning. She said, "Although I believe that giving students grammar exercises is not helpful in engaging them in meaningful communication, they expressed a wish for grammar practice. And I respect their awareness of their learning styles" (April 28, 1999, journal).

As Freeman (1996) puts it, Zeynep's new experience seems to have defamiliarized the previous experience, thereby changing her thinking and helping her to reconstruct her beliefs about teaching and her own practice.

\section{Arzu's Case}

Arzu was the reading and writing teacher of 22 intermediate-level EFL students. As shown in Zeynep's notes on teacher dialogue (February 2, 1999) and Arzu's journal (February 5,1999), Arzu had a discipline problem in her class. The students in general disrupted classroom instruction by talking continually among themselves in Turkish on topics unrelated to the goals of 
the lesson. Arzu would ask a couple of these students to be quiet and they would, until she turned to tell another couple to be quiet. Talking seemed to erupt in several places at once and was a persistent habit for most of the students. Arzu used various means at her disposal to reestablish order such as stopping the activity and explaining to the students how they disrupted the flow of activities, scolding the students, or calmly asking the class to be quiet. After discussing the problem with Zeynep, Arzu decided to focus more on creating a friendly learning environment. In her journal she said,

I am really glad that I observed how Zeynep tried to cope with her problems. Maybe I should try harder to encourage a more friendly atmosphere in class. These people are open to humor, for example, I really like it when they laugh. (February 12, 1999, journal)

As another way of fostering a friendly atmosphere in the class, she encouraged students to be challenging. She wrote:

This morning we were discussing with Zeynep that students should be openly encouraged to challenge ideas, even ideas of teachers. This might make the class more interesting. Zeynep suggested that maybe this would to a certain extent prevent disruptions. Maybe this way even slower students can be successful. It's worth trying. (February 19, 1999, notes on teacher dialogue)

As in Zeynep's case, Arzu also tried to create a friendly learning environment by encouraging student involvement. In week 12 Arzu wrote in her journal that she had finally negotiated an arrangement whereby order was sustained in what she believed to be a friendly learning environment,

At last, the class has been mostly quiet for two weeks in a row. It is wonderful to teach without struggling to keep people quiet. The students all seem happy with this arrangement too. This really is a nice class. (May 21, 1999, journal)

It is clear that Arzu had discipline problems in her class, and this was partly because she needed to reconsider her beliefs about the teacher's control of the class and how to maintain a classroom atmosphere conducive to learning. Discussions with Zeynep helped her to develop a new understanding of the teacher's control of the class and learning needs of the students. By the time data collection was over, she had adopted some new strategies for establishing order while inviting more student participation. She started to believe more strongly that the key issue was finding enjoyable ways of teaching. In her journals she wrote, "I like all of my students and I don't want to alienate any of them" (April 29, 1999, journal). Moreover, discussions with Zeynep helped her to realize that encouraging student interest and involvement can lead to meaningful communication in the classroom. For example, 
when a student asked questions or made comments not exactly related to the topic of focus, or challenged an idea, she did her best to find ways of incorporating this input into ongoing discussion without worrying too much about the flow of activities she had planned for that class. Toward the end of the study Arzu managed to encourage more students to relate the topics in the reading texts to their personal experience. Even those who had not paid attention to the ongoing class activities at the beginning started to contribute to class discussions.

During their collaboration to explore their teaching, Arzu and Zeynep examined their own routine practice and tried to change their teaching behavior in order to improve their classroom effectiveness. Engaging these two teachers in dialogue with a colleague about their teaching encouraged practice-oriented reflection. Collaboration in this sense provided them with social support for reflection and opportunities to learn from each other while each tried to solve a problem in her respective class. The activities such as discussions after observation of each other's classes, journal writing, and stimulated recall techniques using videotapes helped these teachers to analyze their classes through delayed reflection, and this helped them to bring about changes in their teaching behavior that created a more positive atmosphere in their classrooms. As a result, Zeynep developed a more flexible attitude toward students' preferred learning styles, whereas Arzu developed strategies to maintain more student participation. In other words, collaboration in this case did indeed positively affect classroom practice.

To answer the second part of the research question, Does collaborative reflection affect EFL teachers' attitudes toward teaching? the teachers' selfreports of their beliefs about the characteristics of an ideal teacher and to what extent they had these characteristics were analyzed. As shown in Table 1, Zeynep's first self-report included 12 attributes and her second report 17 attributes.

A comparison of the first and second self-reports indicates that they contain the same attributes related to the category of personal qualities as a teacher: (a) high self-esteem; (b) admits her limitations; (c) hard-working; (d) flexible; (e) punctual; and (f) informed about her subject. When the two reports are compared in relation to the category of teaching behavior, it is observed that the first contains six attributes: (a) fair in assessment; (b) enjoys teaching; (c) never loses calm; (d) well prepared and organized; (e) empathizes with students; and (f) keeps distance without being hostile. Zeynep's second report contains the first four attributes mentioned in the first report in relation to teaching behavior. However, the second report does not include the attributes empathizes with students and keeps distance without being hostile, but instead includes four new attributes related to teaching behavior: (a) cares about her students; (b) respects different learning styles; (c) easygoing in class; and (d) creates friendly atmosphere in class. 
Table 1

Attributes Mentioned in Zeynep's Self-Reports of Beliefs About Teaching

\begin{tabular}{ll} 
First Self-Report & Second Self-Report \\
\hline Personal qualities as a teacher & Personal qualities as a teacher \\
P high self-esteem & P high self-esteem \\
P admits her limitations & P admits her limitations \\
W hard-working & W hard-working \\
P flexible & P flexible \\
W punctual & W punctual \\
P informed about her subject & P informed about her subject \\
Teaching behavior & Teaching behavior \\
P fair in assessment & P fair in assessment \\
P enjoys teaching & P enjoys teaching \\
W never loses calm & W never loses calm \\
P well prepared and organized & P well prepared and organized \\
W empathizes with students & P cares about her students \\
W keeps distance without being hostile & P respects different learning styles \\
& P easygoing in class \\
& P creates friendly atmosphere in class \\
& Professional development \\
& W has continual training in her field \\
& W reads journals and other publications \\
& W shares ideas with colleagues
\end{tabular}

$\mathrm{P}=$ possesses equally, $\mathrm{W}=$ currently working on.

These differences in the two records concerning the traits related to teaching behavior can perhaps be explained by Zeynep's concern about coping with the problem in her class. As mentioned above, creating a friendly atmosphere was a strategy she tried to apply while trying to cope with the problem in her class. The attribute easygoing in class may be related to the strategy of creating a friendly atmosphere in class. Moreover, the addition of respect for different learning styles may be attributed to Zeynep's final decision to give grammar exercises to her students for homework.

Analysis of Zeynep's two reports also indicates that the second includes qualities related to professional development: has continual training in her field; reads journals and other publications; and shares ideas with colleagues. Her heightened awareness of professional development attributes may have been the result of reflecting on her teaching and relating that reflection to her reading in the field. She wrote, 
One nice thing about reading is that it does give me a lot to think about regarding my teaching. There are a lot of other good books and articles suggested in these books. I no longer feel intimidated by such readings. (May 21, 1999, journal)

In addition, as can be seen in Table 1, Zeynep mentioned the same attributes in both her reports as the attributes she possessed or was currently trying to improve. Collaborative reflection affected Zeynep's beliefs about the characteristics of an ideal teacher, but not her beliefs about to what extent she possessed those characteristics.

As shown in Table 2, Arzu's first self-report indicates 11 attributes that she believes describe a good teacher, and her second record includes 18. A comparison of Arzu's two self-reports shows that they contain the same attributes related to personal qualities as a teacher; (a) flexible; (b) risk-taker; (c) has good memory; (d) humorous; and (e) energetic and dramatic.

When the two reports are compared in relation to teaching behavior, it can be seen that the second report contains the six attributes included in the first report: (a) encourages participation; (b) gives homework regularly; (c) fair in assessment; (d) well prepared and organized; (e) respects students; and $(f)$ in control of the class and materials. However, the second report also includes three new attributes related to teaching behavior: (a) maintains classroom environment conducive to learning; (b) finds enjoyable ways of teaching; and (c) considers learning needs of students. Arzu's addition of these attributes to her second report may reflect her basic concern with control of the class through these strategies. The addition of considering learning needs of students corresponds to the trait added in Zeynep's second report, respects different learning styles. This may indicate that these teachers affected each other's conceptions of teaching. An analysis of Arzu's journal indicates that her reading also influenced her conception of teaching. She wrote,

From my readings, I gather that metacognitive training is important. It is one way of creating positive atmosphere for learning. I can for example, raise their awareness of the reading strategies available to them. (April 21, 1999, journal)

In another journal entry she wrote, "From my reading so far I gather that there is no one definition of what a good teacher is. I have my ideas. These are tentative of course, subject to change" (April 26, 1999, journal).

Arzu also added to her second report four attributes related to professional development: (a) shares ideas with colleagues; (b) continually reads; (c) explores teaching; and (d) reflects on her practice. These attributes related to professional development in the second self-report may have been added as a result of her reflection on her teaching during data collection and relating this activity to what she had read before and during data collection. 
Table 2

Attributes Mentioned in Arzu's Self-Reports of Beliefs About Teaching

\begin{tabular}{ll} 
First Self-Report & Second Self-Report \\
\hline Personal qualities as a teacher & Personal qualities as a teacher \\
P flexible & P flexible \\
P risk-taker & P risk-taker \\
P has good memory & P has good memory \\
P humorous & P humorous \\
P energetic and dramatic & P energetic and dramatic \\
Teaching behavior & Teaching behavior \\
Wencourages participation & W encourages participation \\
W gives homework regularly & W gives homework regularly \\
P fair in assessment & P fair in assessment \\
P well prepared and organized & P well prepared and organized \\
P respects students & P respects students \\
Win control of the class and materials & W in control of the class and materials \\
& W maintains classroom environment conducive to learning \\
& W finds enjoyable ways of teaching \\
& W considers learning needs of students \\
& Professional development \\
& P shares ideas with colleagues \\
& W continually reads \\
& P explores teaching \\
P reflects on her practice
\end{tabular}

$P=$ possesses equally,$W=$ currently working on

As indicated in Table 2, Arzu mentioned the same attributes in both her reports as the attributes she possessed or was trying to improve. Collaborative reflection affected Arzu's beliefs about the characteristics of an ideal teacher, although her beliefs did not change concerning to what extent she possessed these characteristics.

\section{Teachers' Attitudes Toward the Process of Collaboration}

The analysis of data other than self-reports of beliefs about teaching indicates further changes in both teachers. Both reported that they had never kept a journal before, but that they intended to continue the practice. For example, Zeynep wrote:

I'm not much of a journal keeper but I'll probably do this again. I like writing, and I like writing about my students. Wouldn't it be great to go back years later and read about them? I doubt that I'll write every day, 
but when something important happens, I would like to have a record of it. (May 28, 1999, journal)

And Arzu wrote:

This is my first teacher's journal. I like it. It helps to have something to look back on so I can see where I've been... This journal isn't going to end with the study. I don't see why I never started one before. (May 25, 1999 , journal)

In addition, both teachers reported being much more relaxed after data collection than before about teaching in the presence of an observer and with video equipment. For example, Arzu said,

Zeynep commented on being observed and recorded. She said she had been observed previously by evaluators and she got used to it but was never comfortable about it. Now she says, she feels more relaxed about it. And she said that having analyzed hours of herself teaching, she feels better about being observed. (May 14, 1999, notes on teacher dialogue)

Arzu wrote the following segment in her journal concerning herself,

I don't get nervous easily, but I still have trouble with official observers. And I don't think I would have liked being taped. But having been observed for so many hours by Zeynep and seeing her notes, and also having analyzed my practice, I think I like my teaching. I don't think I'll feel quite so nervous in the future before an observation, and I don't think I'll mind being videotaped. (May 6, 1999)

The participants seem to have changed their attitudes toward teaching in various ways during and after collaborative reflection on their practice. During data collection both Zeynep and Arzu became more interested in qualities related to professional development. In addition, both participants increased their appreciation for keeping a teacher's journal and both found themselves more comfortable with being observed and videotaped while teaching. Both teachers pointed out that although the process of collaboration took time, it was beneficial for developing the skills they needed to explore their teaching practice.

\section{Conclusion}

The participants in this study examined their teaching practice and the values it is intended to serve during the process of their collaboration. Through this expanded awareness of their own practice they developed strategies to cope with their problems and initiated changes in their teaching behaviors. In addition, during the process of reflection they were engaged in deconstructing and transforming existing beliefs. 
The findings of the present study with EFL teachers support earlier findings in EFL settings that collaborative reflection partnerships based on mutual respect and trust between experienced or inexperienced teachers and supervisors or researchers lead to a process of discovery about teaching possibilities and a new way of understanding one's teaching practice (Gebhard \& Motonaga, 1992; Farrel, 1998; Roberts, 1998).

Moreover, the arguments that the way to bring about change in teaching behavior and attitudes toward teaching is to give teachers the opportunity to interact by engaging in conversations about their own classroom practices (Griffiths \& Tann, 1992; Richardson, 1997; Roberts, 1998; Rudduck, 1991) find support in the present study. The dialogue in this particular case required elaboration and extension of ideas. Peer suggestions during the process of collaborative reflection required reformulation of the beliefs and ideas or rethinking of the original statements.

As in most other countries, because of their teaching load teachers in Turkey have little chance to observe others' teaching and little opportunity except informally to engage in dialogue about practice. Moreover, as Rudduck (1991) pointed out, teachers in schools in general do not see analysis and reflection as part of their mainstream image of professional practice, mainly because integrating research into the role of a teacher is not yet a widespread practice. Hence it is necessary, as Somekh (1993) has argued, to instill the idea that teacher research, like teaching, is a practical activity and that it has a direct bearing on what happens in the classroom. In this vein, school administrators can provide teachers with support to develop observation and research skills that will enable them to explore teaching. One obvious way is to engage them on a voluntary basis in dialogue with colleagues to explore teaching as part of a staff or curriculum development project where teachers may contribute to the decision-making process. As Pennington (1992) pointed out, one cannot expect a person to be willing and committed to any work in which she or he has no power to change the state of things. During the process of reflection, a supervisor or teacher educator can give support in managing the whole process as well as help the teachers to develop the necessary skills to explore their own teaching or that of others and to analyze the outcomes of their practice. Moreover, if teachers engaged in such activities received incentives and recognition, this would encourage wider participation. Thus a positive climate may be created that provides opportunities for teachers to realize their potential as part of professional development that engenders self-empowerment.

\section{Note}

At the end of the project 10 teachers (four native speakers of English and six native speakers of Turkish) in this institute contacted me and told me that they were interested in participating in the project if it is undertaken again. 


\section{Acknowledgments}

Many thanks to the two anonymous readers for their valuable comments and suggestions on the first version of this article. The author is especially indebted to the editors for their encouraging comments on the second version of this article. The author also thanks the Bogaziçi University Research Fund without whose grant this project (code no. 99D601) could not have materialized.

\section{The Author}

Ayşe Akyel is a professor of foreign language education at Bogaziçi University, Faculty of Education, Istanbul, Turkey. She teaches TEFL methodology and skills, teacher education, and literature in EFL courses at both the graduate and undergraduate levels. She has published articles on EFL writing, teacher education, the use of literature in EFL and ESP in Belgium, Canada, the United Kingdom, Sweden, Spain, and Turkey. Telephone: +90212 2631540 Ext. 1498; Fax: +90 21225750 36; e-mail: akyel@boun.edu.tr.

\section{References}

Bailey, K.M., Bergthold, B., Brunstein, B., Jagodzinski, N., Halbrook, M.P., Truman, J., Waibluth, Y., \& Zambol, J. (1995). The language learners' autobiography: Examining the apprenticeship of observation. In D. Freeman \& J.C. Richards (Eds.), Teacher learning in language teaching (pp. 11-30). Cambridge, MA: Cambridge University Press.

Carter, K. (1993). The place of story in the study of teaching and teacher education. Educational Researcher, 22(1), 5-12, 18.

Davydov, V.V. (1995). The influence of LA: Vygotskyan education theory, research, and practice. Educational Researcher, 4(3), 12-21.

Driver, R., Asako, H., Leech, J., Mortimer, E., \& Scott, P. (1994). Constructing scientific knowledge in the classroom. Educational Researcher, 23(7), 5-12.

Elbaz, S. (1990). Knowledge and discourse: The evolution of research on teacher thinking. In C. Day, M. Pope, \& P. Denicole (Eds.), Insights into teacher thinking and action. London: Falmer.

Ericson, K.A., \& Simon, H.A. (1980). Verbal reports of data. Psychological Review, 87, 125-221.

Farrel, T. (1998). Critical friendship in ELT teacher development. Prospect, 13(2), 78-88.

Farrel, T. (in press). Collaboration and reflection: Colleagues helping each other develop.

Freeman, D. (1989). Teacher training, development and decision making: A model of teaching related strategies for language teacher education. TESOL Quarterly, 23, 27-45.

Freeman, D. (1996). Renaming experience/reconstructing practice: Developing new understandings of teaching. In D. Freeman \& J.C. Richards (Eds.), Teacher learning in language teaching (pp. 221-41). New York: Cambridge University Press.

Gebhard J.G., \& Motonaga, A.U. (1992). The power of observation: Make a wish, make a dream, imagine all the possibilities. In D. Nunan (Ed.), Collaborative language learning and teaching (pp. 179-189). Cambridge, MA: Cambridge University Press.

Griffiths, M., \& Tann, S. (1992). Using reflective practice to link personal and public theories. Journal of Education for Teaching, 18(1), 69-84.

Kauchak, D.P., \& Eggen, P.H. (1997). Learning and teaching methods. Boston, MA: Allyn and Bacon.

Newman F., \& Holzman, L. (1995). Lev Vygotsky. London: Routledge.

Nunan, D. (1989). Understanding the second language classroom. New York: Prentice-Hall.

Nunan, D. (1992a). Towards a collaborative approach to curriculum development. In D. Nunan (Ed.), Collaborative language learning and teaching (pp. 230-247). Cambridge, MA: Cambridge University Press.

Nunan, D. (1992b). Language teaching methododogy. New York: Prentice-Hall.

Olson, M. (1997). Collaboration: An epistemological shift. In J. Chritianson, L. Guld, C. Ktentez, \& M. Merers (Eds.), Teachers' professional learning (pp. 205-223). London: Falmer. 
Pennington, M.C. (1992). Motivating English language teachers through job enrichment. Language, Culture and Curriculum, 5(3), 199-217.

Richards, J., \& Lockhart, C. (1994). Reflective teaching in second language classroom. Cambridge, MA: Cambridge University Press.

Richardson, V. (1997). Constructivist teaching and teacher education. In V. Richardson (Ed.), Constructivist teacher education (pp. 3-15). London: Falmer.

Roberts, J. (1998). Language teacher education. London: Arnold.

Rudduck, J. (1991). The language of consciousness and the landscape of action: tensions in teacher education. British Educational Research Journal, 17, 319-331.

Seaman, A., Meadon, P., \& Sweeny, M. (1997). Collaboration, reflection and professional growth: A mentoring program for adult ESL teachers. TESOL Journal, 4, 31-34.

Somekh, B. (1993). Duality in educational research: The contribution of classroom teachers. In J. Edge \& K. Richards (Eds), Teachers develop teachers research: Papers on classroom research. Research and teacher development. London: Heinemann.

Sturman, P. (1992). Team teaching: A case study from Japan. In D. Nunan (Ed.), Collaborative language learning and teaching (pp.141-162). Cambridge, MA: Cambridge University Press.

Van Lier, L. (1988). The classroom and the language learner: Ethnography and second-language classrom research. London: Longman.

\section{Appendix}

Transcription Conventions (van Lier, 1988)

$\mathrm{T}$

L1, L2, etc.

L

$\mathrm{L} 3$ ?

LL

/yes/yah//ok//

$=$

, etc.

?

!

OK. now. we. etc. intonation

so; the next thing

o:r, the;;i, etc.
: teacher

: identified learner

: unidentified learner

: probably learner 3 (L3)

: several or all learners simultaneously

: overlapping or simultaneous listening responses, brief comments, etc., by two, three, or an unspecified number of learners

: turn continues below, at the next identical symbol- if inserted at the end one speaker's turn and the beginning of the next speaker's adjacent turn, it indicates that there is no gap at all between the two turns

: pause; three periods approximate one second: These periods are separated from the preceding word by a space

: rising intonation, not necessarily a question

: strong emphasis with falling intonation

: a period unseparated from the preceding word indicates falling

: a comma indicates low-rising intonation, suggesting continuation

: one or more semi-colons indicate lengthening of the preceding sound 
emphasis

OK? so, next

.....(radio)

((unint)), ((coughs))

no-

yesterday Peter went

[si:m]
: italic type indicates marked prominence through pitch or amplitude

: onset and end of overlap or insertion of concurrent turn; for convenience a space can be inserted in the turn above, but this does not indicate a pause unless marked by periods

The segments start with classroom interaction. At the exact place where the teacher stopped the tape during the stimulated recall procedure, the comments begin. The segments of classroom interaction provide context for the recall comments. A capital " $R$ " indicates the researcher asking questions or commenting in an attempt to clarify what the teacher was trying to say.

\section{A sample transcript segment of Arzu's classroom interaction and stimulated recall}

L4 line 24? ((17 second pause)) line 26? ((14 second pause))

$\mathrm{T}$ I'm on line $24 .$. where are you?

L4 26. ((3 second pause))

Thuh?.. no.

\section{L4 what?}

T I'm trying . to finish . line 24 ( $(3$ second pause)) line 23. ...... Rumeysa, Teoman, don't act like children. . please. ((silence))

\section{Stimulated Recall}

T: I've been thinking about this episode ever since I left the classroom. these students were going too far. I don't like scolding or belittling students, but notice the silence. they know I don't do this, so it had the impact I wanted. I'm really glad I got this on tape.

$R$ : were you thinking about all this at the time?

T: no, actually, I wasn't thinking about it at all . I was thinking that it must be nearly break time, and I didn't want them disintegrating into chaos . it gets tougher to keep them participating as break gets closer.

Note: Observer notes indicate that these two students were often talking in class when they should have been listening. This time they seemed to get more carried away than usual. They started playing around and got noisier than usual. 